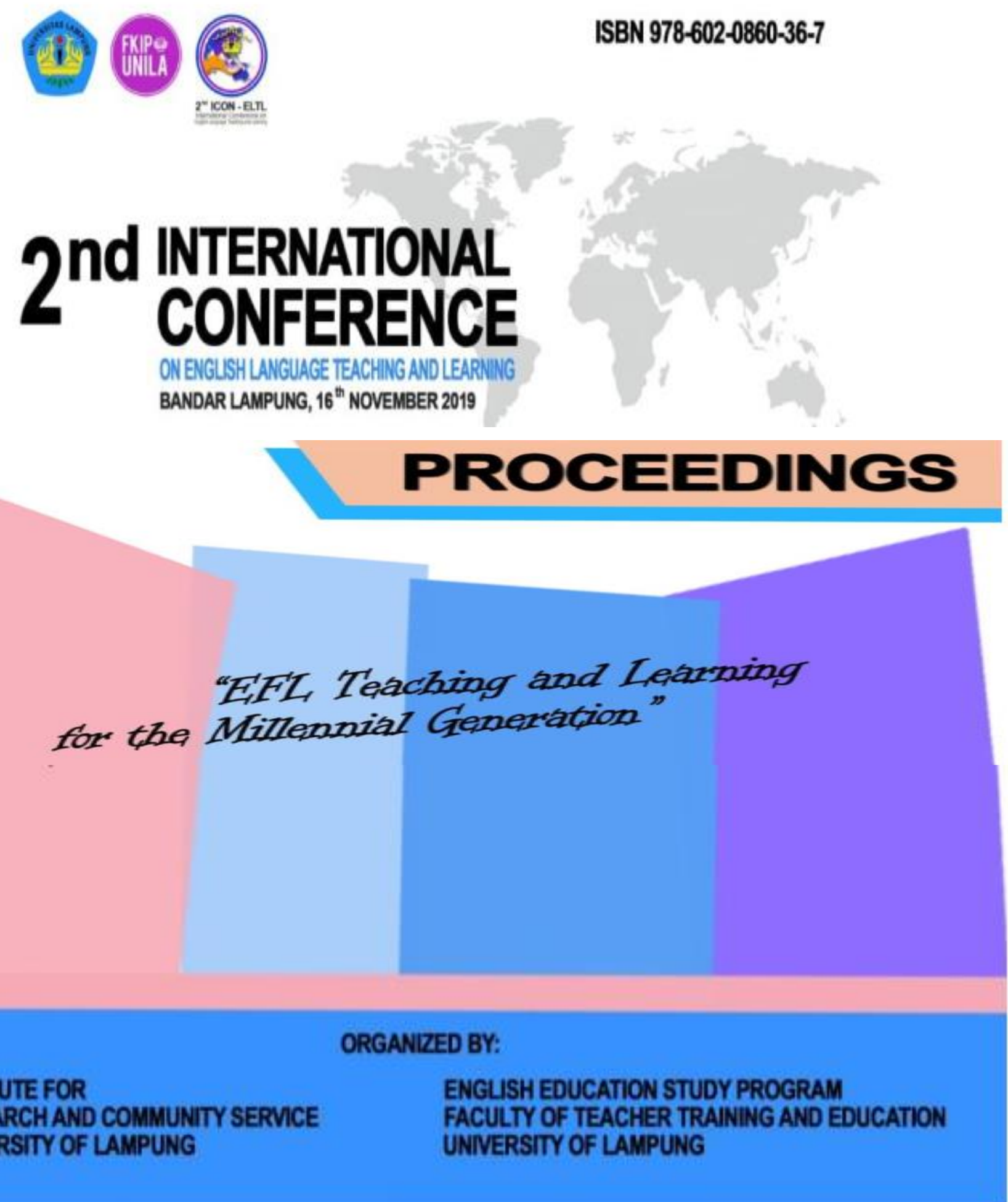




\section{Preface}

The English Education Study Program, Department of Language and Arts Education, Faculty of Teacher Training and Education, University of Lampung was honored to host the 2nd International Conference on English Language Teaching and Learning (2nd ICON-ELTL) in the heart of the city of Bandar Lampung on 16 November 2019. The Vice Rector for Academic Affairs of Lampung University, Prof. Dr. Bujang Rahman, opened the conference followed by a welcome address by Dr Ari Nurweni, the Conference Chair.

The conference theme "EFL Teaching and Learning for the Millennial Generation" was an invitation to discuss English language teaching and learning - related issues (including blended learning for millennials, communication and information in language teaching, learning styles and strategies for millennial EFL learners, curriculum and material development, engaging literature and culture in teaching millennial generations, and other relevant topics). The aim of the conference was to bring together academics, researchers, teachers and students to exchange ideas, experiences and research findings in the field of English language teaching and learning for millennial generations to make better, efficient and impactful teaching and learning.

The conference was attended by 226 participants and 43 presenters from all over Indonesia. Four keynote papers were delivered on the conference day. The first was presented by Dr. Hisham bin Dzakiria (Universiti Utara Malaysia), and the second was delivered by Dr. POH Soon Koh (NTU, Singapore). Other two invited keynote papers were also presented by Dr. Muhammad Sukirlan (University of Lampung) and Sydney Garvis (a fellowship program lecturer from USA to Unsyiah). In addition, 43 papers were also presented by registered presenters in the parallel sessions of the conference.

The conference program represents the efforts of many individuals. Therefore, we would like to express our gratitude to the members of the organizing committee for putting much effort into ensuring the success of day-to-day operation of the conference and the reviewers for their hard work in reviewing submissions. We also thank the four invited keynote speakers for sharing their insights with us. Finally, the conference would not be possible without the excellent papers contributed by authors. We thank all authors for their contributions and participation in the 2nd ICON-ELTL 2019. We hope that this conference will further stimulate research on English language teaching and learning in today's advancement of digital era and provide academics, researchers, teachers, and students with better understanding, knowledge, and ideas for further research. We feel honored to serve the best recent scientific knowledge and development in the field of English language teaching and learning. In addition, we also hope that these proceedings will furnish scholars from all over the world with an excellent reference book.

Realizing that there were still some weaknesses during the conference, we do have an apology to make to everyone and we hope we will be able to hold better international conferences in the future. Finally, it was with great pleasure that we had the opportunity to host such a conference. Thank you.

\section{Ari Nurweni Conference Chair}

\author{
Gede Eka Putrawan \\ Conference Co-Chair
}

V 
Table of Contents

Cover Page i

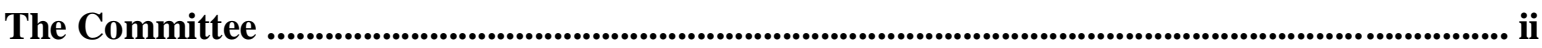

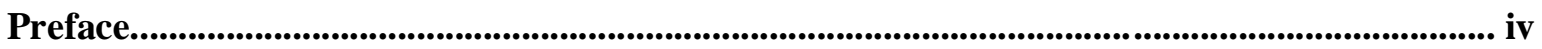

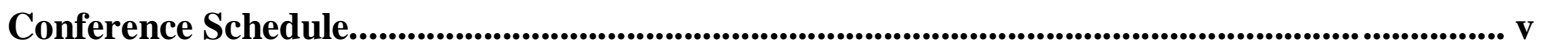

Language Teaching Methods for 21 st Century Learners.................................................................. 1

Sydney Garvis, Fellowship at UNSYIAH, USA

Teaching English as a Foreign Language in Millennial Era: Opportunities and Challenges... 2

Muhammad Sukirlan, Universitas Lampung

Blending the Right Pedagogical Approaches on English Education for the Millennial

Generation: Exploring the Benefits of Virtual Platform .

Hisham bin Dzakiria, Universiti Utara Malaysia

"Match Your Teaching Styles with the Millennials' Learning Styles". What about Cultural

Ways of Learning?

POH Soon Koh, Institute of Education, Nanyang Technological University

Corpus-based Study: Students' Lexical Coverage through Business Plan Report

Writing...

Dian Puspita, Universitas Teknokrat Indonesia

Finding an Intersection among Vision, Motivation and Language Acquisition: A Study in

Indonesian Context

$39-50$

Adhi Nurhartant \& Gita Hilmi Prakoso, Universitas Mitra Indonesia; Universitas Lampung

Developing E-Module of English for Tourism Based on Brain-Based Learning Approach at

State Polytechnic of Lampung

Anwar Rahman, Politeknik Negeri Lampung

Improving Students' English Quality in Millennial Era by Social Media $66-74$

Dewi Sri Kuning, STKIP Muhammadiyah Kotabumi

The Use of VOA (Voice Of America) toward Students' Speaking Ability. $75-86$

Eva Faliyanti \& Eli Setia Anggraena, Universitas Muhammadiyah Metro

Facilitating Meaning Recognition of English Vocabulary through Audio-visual Input: A

Study of Indonesian learners.

$87-96$

Fajar Riyantika, Universitas Lampung

Padlet as an Alternative Learning Journal in Listening Class

$97-103$

Nunun Indrasari, UIN Radin Inten, Lampung

Digital Story: Its Effect on Students' Pronunciation Mastery $104-116$

Yogi Era Reforma \& Septa Aryanika, UIN Radin Inten, Lampung

The Use of Instagram to Boost Students' Writing Skill in Explanation Text

$117-124$

Fenny Thresia \& Nur Khairunnisa, Universitas Muhammadiyah Metro

E-comics in Teaching: Using Comic Strip Creators to Enhance Junior High School Students'

Writing Ability $126-133$

Achmad Yudi Wahyudin, Universitas Teknokrat Indonesia

Enhancing Student's Vocabulary Mastery through Project-Based Learning in The EFL

Classroom.

Fatimah Mulyasari, Universitas Teknokrat Indonesia

The Impact of Reciprocal Teaching Strategy towards Students' Reading Comprehension at

Eight Grade SMPN 4 Metro Academic Year 2018/2019 $142-148$

Syaifudin Latif D \& InasHafidzah, Universitas Muhammadiyah Metro

Code Switching in Teaching English to Postgraduate Students 149 - 155

Lolita Falina \& Yanti Wirza, Universitas Pendidikan Indonesia 
Small Group Discussion (SGD) and Jigsaw Technique in Teaching Speaking for Eleventh Grade Students of SMAN 1 Simpang Empat Batulicin. $156-162$

Rina Listia \& Mutiara Erwani, Universitas Lambung Mangkurat, Indonesia

Improving the Students' Speaking Achievement through Detailing Technique $163-171$ Aswadi Jaya,Marleni \& Asti Veto Mortini, Universitas PGRI Palembang

The Application of Model Challenge-Based Learning for Higher Institution Students.172 - 178 Hery Yufrizal, Universitas Lampung

An Analysis of Errors in Students' Written English Sentences: A Case Study on Indonesian EFL Learners 179 - 189

Berlinda Mandasari, Universitas Teknokrat Indonesia

The Implementation of Think-Pair-Share Technique to Introverted Students to Improve

Their Speaking Ability at the Second Grade of SMA Swadhipa Natar 190 - 195

Bayu Didik Setyawan, Deddy Supriad \& Gede Eka Putrawan, Universitas Lampung

The Factors Contribute to Millennials' Learning Style in EFL Context $196-203$

Rini Susilowati,Universitas Muhammadiyah Kotabumi

The Implementation of Mind Mapping Technique to Improve Students' Writing Skill of

Descriptive Text at the Second Grade of MTSN 3 Lampung Utara. $204-210$

Sudirman, Burhanuddin \& Dedi Hermansyah, Universitas Lampung

The Influence of Question Answer Relationship (QAR) toward Students Reading Comprehension $211-220$

Lilis Sholihah, Universitas Lampung

Local Wisdom-based EFL Teaching: Internalizing the Values of Local Culture to

Millennia Learners $221-231$

Nurul Puspita \& Umar Alfaruq A. Hasyim, UIN Radin Inten; IAIMNU Metro

Students' Perception toward the Implementation of the Modified Jigsaw Technique for Their Writing Ability 232 - 239

Rifka Arina Ruantika, Ujang Suparman, Ari Nurweni,Universitas Lampung

The Cross Cultural Perceptions on the Politeness of the Requests Realized by Indonesian EFL

Learners in School Context 240 - 249

Seniarika, Hery Yufrizal, Tuntun Sinaga, Universitas Lampung

Teaching Procedure Text Using Islamic Tutorial Video $250-259$

Dian Shafwati, Universitas Lampung

The Use of Animation Video to Improve Students' Reading Comprehension in Narrative Text to the Second Grade Students of Smpn 1 Lahat, South Sumatera 260 - 266

Dhea Fernanda, Cucu Sutarsyah, Ari Nurweni

Lexical and Grammatical Collocation in Presidential Election (Study of Gender Based on

Writing Analysis) $267-274$

Fitri palupi \& Arvi Puspita Riani, Universitas Muhammadiyah Metro

The Key Elements of Forensic Linguistics. $275-280$

Hermansyah, Diana Luspa, Herlina, Universitas PGRI Palembang

An Analysis of Figurative Language and Its Meaning in Robert Frost's Poems: Stopping by Woods on a Snowy Evening and The Road Not Taken. $281-286$

Melina Sari, Universitas Lampung

Provisioning English as a Life Skill: Integrating the Google Form Simulation of Job

Application Portofolio for 12 Grade Students of Technology Major at Vocational Schools. 
Nina Fatriana, SMKN 2 Kalianda, Lampung, Indonesia

The Use of Integrated Technology of Substitution, Augmentation, Modification and

Redefinition (SAMR) in Increasing English Skill at STIK Siti Khadijah Palembang... 297 - 311

Nyayu Yayu Suryani \& Harpiansi, Sekolah Tinggi Ilmu Kesehatan Siti Khadijah Palembang

Direct and Indirect Corrective Feedback on Accuracy Students' Ability in Writing an

Essay

Rulik Setiani, Universitas Muhammadiyah Kotabumi

Negotiations of Meaning, Corrective Feedbacks and Backchannels II Oral

Communications.

Sigit Suharjono, Universitas Muhammadiyah Kotabumi

The Use of ICT in English Language Learning by EFL University Students $334-343$

Tubagus Zam Zam Al Arif, Universitas Jambi, Indonesia

Flipping Classroom for Young EFL Learners

Dameria Magdalena Sidabalok, Harpain harpain \& Rafista Deviyanti, Universitas Bandar

Lampung;Universitas Lampung 


\title{
LOCAL WISDOM BASED EFL TEACHING: INTERNALIZING THE VALUES OF LOCAL CULTURE TO MILLENNIAL LEARNERS
}

\author{
Nurul Puspita ${ }^{1}$, Umar Alfaruq A. Hasyim² \\ UIN Raden Intan Lampung ${ }^{1}$ \\ IAIMNU Metro Lampung ${ }^{2}$ \\ nurulpuspita17@gmail.com
}

\begin{abstract}
Millennial learners have dynamics ways of thinking. Moreover, they also think and solve the problems faster than previous generation. It is because; these learners live in the era of industrial 4.0 where informatics technology spreads in all aspects of human life. Therefore, these characteristics lead the millennial learners seem perfect. Millennial learners can learn many skills for their future life easily through their gadget. One of skills should be mastered by the millennial is English. However, the goal of teaching and learning English is not only improving linguistics competence but also building good character of the learners. Therefore, this research aims at guiding them to learn target language. In other hand, this research also aims at assist them to always remaining their local wisdom, build their local wisdom based character and promotes their local culture globally. It is applied by internalizing the local culture values to the learners in EFL teaching. This research is descriptive qualitative that describing the process of internalizing the local culture in the process of EFL teaching especially descriptive writing. This research was conducted in the third semester of English department in UIN Raden Intan Lampung. In conducting the teaching and learning process the lecturers choose authentic materials that deal with the local culture of Lampung. Then, the students find the values of the culture and describe the values in term of descriptive writing.
\end{abstract}

Key word: Local Wisdom, EFL Teaching, Millennial Learners

\section{INTRODUCTION}

Teaching and learning English as Foreign Language (EFL) is not only concerning on the developing of the students' skill on speaking, reading, writing and listening (linguistics mastery) but improving stundents'understanding of the meaning and values of a certain text is also important. Generally, as stated by Sari (2019) that education in Indonesia should prepare the students' competence on technical skills as well as the concepts and the meaning of a certain subject they learn. In EFL context, those issues emerge amongs EFL learners in Indonesia. It is the duty of the teacher to solve those problems, preparing them for technical and conceptual skill.

More specifically, in English as Foreign Language (EFL) teaching and learning, students are mostly prepared to master the four skills of English. However, the students are not prepared for understanding the concept and the meaning of certain text of English being learned. In addition, understanding the concept and the meaning of the text and context is very important. It is stated by Sari (2019) that having this competence will lead the students see the world and the problems comprehensively and solve the problem wisely.

Therefore, teaching and learning EFL is not only simply pereparing the students to speak, read, listen and write the English text grammatically but also to improve the students' competence to understand the meaning of the content that will lead them not only see, listen and talk a certain topic but feell and understand it comprehensively. 
However, understanding the content of the target language will also emerging new problems. In this case, millennials as EFL learnres are susceptible to be effected by target language culture. Thus, it is possible by the learners to lose their local wisdom as well as their local culture values. One of ways to encaounter the problem is giving local culture content to the students. it is expected to assist them to always remaining and understanding their local wisdom and promotes their local culture globally. Moreover, Septy (2016) informs that dealing with English literacy skill, English materilas with local wisdom content could be used to encourage students learning experience to develop their English literacy skills. It is because that local wisdom is the source containing moral values that naturally emerge and derived from generation to generation in a certain social environment naturally.

In addition, implementing local culture content in English subject will develop and create deepthought of culture philosophically and construct better socio-culture system of the students (Septy, 2016). This construction is needed by the students to prepare them living as a member in a social community. More detail, Arslan (2008) informs that the goal of English language teaching (ELT) should be able to integrate the four skills of English (reading, listening, writing and speaking) and the competence of understanding local wisdom values and norms that is implemented on good characters. In other words, this competence could develop good characters of the students based on moral values that exist in their local wisdom. Besides, it is also giving them chance to share their understanding of the local culture globally.

There were several researchers conducted research on local wisdom in English language teaching. It was Ahmad (2017) developed teaching model based local wisdom to improve students' writing skill. This research and development succeed to improve the students' writing skills as well as their awareness of local wisdom. It was also conducted by Septy (2017), she was successfully informed the building of the EFL learners character by using local wisdom and culture. She also informed the usage of ICT as a media in teaching and learning process.

Thus, this research aims at implementing local culture content in English materials of descriptive writing. It is expected after learning those materials, students will comprehend the content of the materials and take the values of the content. In addition, the students could build good character taken from the moral values in the local culture materials and implemented in their daily life. Then, the values of the local culture can be used to protect them from inappropriate culture of the target language, English. Finally, by using their competence in descriptive writing and the productive skills of English (writing and speaking), students can promote the local culture globally.

\section{Millenial Learners}

Millenial generations or internet generations are a group of people that shaped and learn trough ICT tools and digital devices connected with the internet (Larekang, H. S., et al, 2019). Today, this generation is dominated by people age $23-38$ (Dimock, M, 2019). Therefore, the millenial generation is well-literated young people with information and technology. In addition, they 
have different way of gaining information or learning than previous generations. More specifically, Schwartz, A. C., et al (2018) informs that these generations are good in collaborative learning, understand technology, goal oriented and open to criticism.

Moreover, to complete the above explanations, some researchers explain the differences between millennial generation and the previous generation. It is stated by Jones and Shao (2011) believes that millennial generation is well-known with their competence in utilizing technology. It is also informed by Nicholas (2008), he found that the millennial generation is frequently access internet to obtain information. Millennial as a learner and worker use technology intensively. It is because millennials live in the era of technology 4.0 where technology takes important role in their daily life. In addition, the millennial generations use technology to support them to find new information as well as learning a certain subject (Klein and Liff-Griff, 2009).

Technology provides benefits for the millennial generation, it is stated by Scheidet (2013) the benefits of technology utilization such as developing the quality of work (process and products), facilitating the students to access the resources easily, effecting to the students' way of learning positively, and improving the cognitive skills of the learners. Thus, millennial believes that technology will help them to accomplish their work more than they could without the use of technology. Technology also allows them to obtain and access the information. Technology also is completed with many resources that lead the millennial creates many kinds of products.

In addition, dealing with social and interaction aspect, the millennial generation mostly has good relationship with others (Price, 2009). It is also stated by McCrindle (2003) that this generation is community-oriented due to their values are influenced by social oriented and the spirit of changing the world. Millennial students are more open to express their opinion through direct interaction (face to face) as well as written expression (Promnitz-Hayashi 2011). Furthermore, this generation also performs group work effectively and solves the problems by analyzing the data. It is proven by Nicholas (2008), he found that the millennial students before solving the problems, they analyze the case and solve it together in a group.

Thus, it can be summarized that there are several points about millennial generation. The first is dealing with the implementation of technology, the generation is has good literacy in technology. Millennial generations are confidence to utilize technology for upgrading their work (process and products) and finding the information. The second point is about social interaction, the millennial tends to have good relationship due to implement group work to solve the problems.

\section{Local Wisdom and EFL Teaching}

Learning English as Foreign Language (EFL) in Indonesia is really beneficial to face many future challenges. Furthermore, Indonesian learners as EFL learners must be protected them self and smart in adopting the target language as well as the culture behind it. Sari (2019) assumes that the EFL students are never understand if their life is gradually moving dues to the effect of learning new language and culture. Therefore, it is possible for the students to change their 
culture or habit as the effect of new culture. Thus before learning new language and culture students must pay attention to the regulation (Sari, 2019). It is also important for the EFL learners to understand their own culture as a comparison object and balancing devices.

Generally, an activity dealing with learning must be containing culture, values and norms. It is stated by Diaz (2004) said that the basic principles of life that is existing in the process of learning are transferred through values and norms socio-culturally. This is also happened in the teaching and learning EFL due to Language and culture are two entities that cannot be separated each other's (Hasyim \& Suhono, 2017). Moreover, the process of learning will construct the personal identity of the learners. It is because, as stated before, the learning process provide with the culture in it. Further, the culture consists of belief, values, and rules (Diaz-Rico, 2004). It has values for living explicitly and implicitly. Therefore, the culture is dynamic system that constructs a personal identity transferred through art, law, traditions, knowledge, symbols, meaning, belief and etc (Septy, 2017).

Local wisdom is the identity of a certain group of people. It is values that emerge naturally along with the emergence of the society. Septy (2017) added that local wisdom is the source of conventional value naturally grown up and derived from the social and natural environment that then become philosophical-deep thoughts in controlling and developing better socio-cultural system of a certain group of people.

Every society has different local wisdom; it is a value that useful for the people to manage their socio-cultural system. In Indonesian context, the values of the local wisdom are spread around the country due to Indonesia has variety of social groups. This condition leads Indonesia rich of source local values that can used to build personality, identity and the character of the learners. Then, it is the duty of the teacher and the lecturer to internalize and manage the EFL materials with the values of the local wisdom to the learners. After doing this, it is expected learners use English as means of communication with the good character based on the values of the local wisdom.

In English as Foreign Language (EFL) Teaching and Learning, local wisdom is used to build character of the learners based on their local values. Besides learning linguistics aspects of English namely applied and pure linguistics, the learners should also understand about the communication strategy and the social culture of the target language as well as their own. In detail, Lane in Septy (2017) inform that communicative competence may include (1) ability to adapt (adaptability/flexibility), (2) ability to involve in conversation (conversational involvement), (3) ability to control conversation (conversational management), (4) ability to express empathy (empathy), (5) ability to act effectively (effectiveness), and (6) ability to act appropriately (appropriateness). Therfore, the coomunicative competence is not mere speaking competence. More detail, the communicative competence demand the learners to undertstand the whole text and context of the topic that it is reflected from the personality, characters of the speaker. 
Finally, it can be concluded that learning English as Foreign Languae is not only focusing on linguistics aspects mastery but communicative competence and socio-cultural competence should be also learned. Communicative and socio-cultural based local wisdom competence are benefitial for the learners to build their identity and characters. In addition, it is also give the learners understanding of their local culture values that can protect them from inapropriate target language culture. It is beacuse learning target language such as English will make the learner possibly contaminated inapropriate target language culture. To protect them, EFL teaching and learning should be inserted with local culture contents. The local culture content in teaching and learning process will assist the learners know and undersatnd their culture. Therefore, it is important to learn English as Foreign Language (EFL) along with the learning of the culture or local custome included. It can be said that culture and language teaching and learning cannot be separated.

\section{Teaching and Leaning Writing}

In learning foreign language, language learners begin learning a language from their mother tongue, sometimes encounter mistake (suhono, 2017:72). Moreover, language is a media for communication among individuals or people. It is a signaling system which is operated with symbolic vocal sound to get the purpose of communication. Learning English language is one of science that should be learnt to all the people. English becomes very important and useful for us (Suhono 2017:1) one of aspect of learning English is writing.

Writing is a process that occurs over a period of time, particularly if we take into account the sometimes extended periods of thinking that precede creating an initial draft. Furthermore, writing also defines as a mental activity of skilful decision-making, appropriate for the situation. It means that the writer is able to make decision as consideration to the purpose of writing, the objective of the readers in reading text, situation and condition during the process of writing done.

Moreover, Grundy assumes that writing is like as playing tennis, it is an activity made up of several processes, such as thinking what to write and the order to put it in (1991:7). In the process, writing and thinking are so inseparable, if the researcher cannot think clearly about an idea, he cannot write well. On the contrary, if he has creative thinking in the writing process, the actual writing process will be easier. Meanwhile, Hyland states that writing is seen as a process through which writers discover and reformulates their ideas as they attempt to create meaning (2002). It is more of a problem solving activity that an act of communication. How people approach a writing task as the solution to a series of problems.

In addition, Writing consist of words and these words are put together into paragraphs. Moreover, Sari and Suhono said that - Writing involves transferring a message from our thoughts using language in the written from. By writing, the students can share information and ideas in the written form (2017). As a researcher must be able to arrange the words into 
sentences in the form of the written text in which the reader will eventually understand the ideas and their meaning. Thus, the researcher is demanded to pay the content, organization, vocabulary use, grammatical use, and mechanical considerations such as spelling and punctuation

In general it can be assumed that writing is a thinking process to produce a written text. it is obtained by process of thinking to arrange the words into the sentences, and then the sentences are grouped together into the paragraphs. The result of the written text is reflection of the mental activity of the writer in understanding the context situation that faced by the researcher (Puspita \& Hasyim, 2019)

Because of that, learning to write is not an easy task to do. Many students still make errors and mistakes and, then, they are fossilized (Puspita, 2015). Their interest becomes less and less and students begin to create negative stimuli about learning to write. This condition drives the students to assume that writing is a very difficult task to do. The problem emerges as students are not familiar yet with the types of written discourse in English due to lack of exposure. Consequently, they are not able to or willing to think directly in English. They, then, tend to formulate their ideas in Indonesian language when they express ideas in writing. Afterward they try to translate them into English which is not an easy task and even dangerous.

However, both teacher and students get difficulties to organize writing practice regularly. Teacher does not have proper time allocation in teaching writing. He or she focuses on another skill. Therefore, teacher gives writing activity to students as an out-of-class activity. Students discover lack of clear specific instruction and also lack of control and monitor from teacher during the writing process. It emerges some new problems to students.

\section{Descriptive Text}

Descriptive text is a text that tells and describes about place, thing, and etc. Every genre of text has generic sructures and language features. The descriptive text has differents generic structures and language features. Moreover, Wardiman, et. al. (2008) specified the generic structure of descriptive text into two parts: 1) identification and 2) description. Furhtermore, in identification, the writer identifies the phenomenon to be described. However, in other text genre, the identification is like orientation. It is usually put in the first paragraph and brings us to know about the discussed topic. Moreover, identification usually talks about the topic and the content of the text. Abdul and Norhasanah (2019) add that the identification answers the questions such as what the topic of the text is, and what the text about is. The second part is description, in this part the writer describes the parts of things, parts of physical appearance, qualities (degree of beauty, excellence, worth or value), and other characteristics (prominent aspects that are unique). It is put after identification or next paragraph of identification until final paragraph (Abdul \& Norhasanah, 2019). 


\section{METHODOLOGY}

This study is descriptive qualitative. It aims at describing the implementation of the local wisdom presented in teaching descriptive writing. The subject of the study was English Department students of third semester. The data was obtained from interviews and observation. The data obtained then analyze interactively.

\section{FINDINGS AND DISCUSSION}

The implementation of local culture in teaching writing is presented in the classroom. Before, doing the writing activity, the lecturer explain about the definition of descriptive text. Moreover, the lecturer also gave example of descriptive text. The lecturer also expalined the generic structure and the language features of the descriptive text.

Then, the students did the activity based on the following text. This text was presented in meeting 12, $4^{\text {th }}$ November 2019. It was conducted in the third semester of English department faculty of Tarbiyah and Teacher Training UIN Raden Intan Lampung. The following was the text presented;

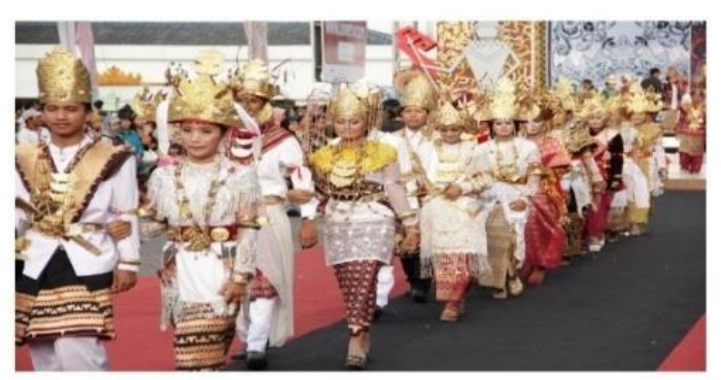

Siger is an important traditional object or device in traditional Lampung rituals. The object is in the form of a golden metal crown that has a very distinctive shape detail. This crown is a symbol of one's honor and social status in Lampung society. Because of the uniqueness of its shape, siger became a regional symbol attached to Lampung Province.

Siger, sigokh in the Saibatin dialect, has a bilateral symmetrical shape, displaying to the left and right of its users. At the top, there are indentations with specific numbers. The number of curves at the top characterizes the origin of the siger region. Apart from the curve, the origin of the siger region can also be recognized from other details such as tufts and tufts
of scale.

In general, variations in the siger form evolve with the development of tradition in indigenous communities in Lampung. This can be seen from the different forms of siger in the Saibatin and Pepadun indigenous communities. Siger in the Saibatin tradition that inhabits the coastal area has seven notches which mean seven adoq (customary titles in the Saibatin community), namely suttan dalom / primce (testimony / clan), king of jukuan /

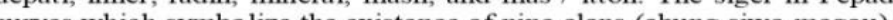
(1)

In addition to the differences between the two indigenous peoples, the inclusion of Hindu-Buddhist and Islamic culture also enriched the variety of siger forms in certain regions. Historically, the form of siger that first developed in Lampung culture was sigokh uha, which had hive curves. This siger has exised, namely the Kinger orinate from the Melinting custom which is similar to the Sigeratin siger but has accents in the form of fringes
that resemble veils. (Ardee / Indonesia Kaya)

https://www.indonesiakaya.com

Figure 1. Descriptive Text 
The following is the teaching and learning process of descriptove writing. in this table presented the activities of the lecturer and the students during the process;

\begin{tabular}{|c|c|c|}
\hline & \multicolumn{2}{|c|}{ Activity } \\
\hline & Lecturer & Student \\
\hline \multirow{3}{*}{$\begin{array}{c}\text { Meeting } 12 \\
\left(4^{\text {th }} \text { Nov }\right. \\
2019)\end{array}$} & 1. Planning & 1. Planning \\
\hline & a. In this session, the lecturer & a. Students paid attention to the \\
\hline & gave an example of the & lecturer explanation . \\
\hline \multirow{3}{*}{$\begin{array}{c}\text { Descriptive } \\
\text { Text } \\
\text { (Siger }\end{array}$} & descriptive text (Siger & b. The students discussed the \\
\hline & crown). Then the lecturer & topic; \\
\hline & discussed the text in detail. It & - Nawo sesat traditional house \\
\hline \multirow[t]{31}{*}{ Crown) } & was about the generic & -Tapis \\
\hline & structure of the text and the & -Sigeh Pengunten dance \\
\hline & language features. & - Melinting dance \\
\hline & b. After that, the lecturer asked & - Seruit \\
\hline & the students to choose one of & - Sekura tradition \\
\hline & topics dealing with local & -Tupping South Lampung \\
\hline & culture of Lampung (sekura & - Cangget dance \\
\hline & dance, melinting dance and & - Bedana dance \\
\hline & etc) & -Tekhapang traditional sword \\
\hline & c. The lecturer asked the & -Ngumbai Lawok \\
\hline & students to find information, & -Ngambabekha \\
\hline & facts and values including in & -Ngebabali \\
\hline & & Those were cultural topics that \\
\hline & & were chosen by several \\
\hline & & students. \\
\hline & & c. Then the students find the facts \\
\hline & & and information of the local \\
\hline & & culture as well as the values \\
\hline & & included. \\
\hline & 2. Drafting & 2. Drafting \\
\hline & a. After finding the & a. The students listed the \\
\hline & information about the a & important information (place, \\
\hline & certain culture, the lecturer & date, and etc). the students also \\
\hline & asked the students to find the & listed the values included in the \\
\hline & important points and values & local culture for example; \\
\hline & of the information obtained. & - Tekhapang traditional \\
\hline & b. Then the lecturer guide them & weapon is the symbol of \\
\hline & to develop topic sentence & courage for man to protect \\
\hline & c. Then the lecturer guide the & his family \\
\hline & students to write out line and & - Melinting dance shows the \\
\hline & write the paragraph & \\
\hline
\end{tabular}




\begin{tabular}{ll}
\hline & friendliness \\
\cline { 2 - 3 } 3. Revising and Editing & 3. Revising and Editing \\
$\begin{array}{ll}\text { a. Lecturer asked the students } & \text { a. Students together with their } \\
\text { to do peer editing. } & \text { peer did the editing of their draft } \\
\text { b. then the lecturer discussed } & \text { b. Students and the lecturer } \\
\text { the result of peer editing and } & \text { discuss revised draft } \\
\text { gave suggestion } & \end{array}$ \\
\hline
\end{tabular}

\section{Table 1. Teaching and Learning Process}

The teaching and learning process was conducted in three steps namely planning, drafting, revising and editing. The planning process was conducted in order to find idea about a topic. In this case, the teaching and learning process was about descriptive text. The lecturer gave the example of descriptive text; it was about the siger crown. The text described the local culture of Lampung in term of traditional object. Then the lecturer and the students discussed the language features and generic structures of the text. After that, the lecturer guided the students to find the other local culture of Lampung as a topic of writing. There were several local culture of Lampung had been chosen by the students such as; Nawo sesat traditional house, Tapis, Sigeh Pengunten dance, Melinting dance, Seruit, Sekura tradition, Tupping South Lampung, Cangget dance, Bedana dance, Tekhapang traditional weapon, Ngumbai Lawok, Ngambabekha and Ngebabali.

The second phase was drafting. In this phase, the lecturer guided the students to list important points and the values included in the local culture chosen. After that, the lecturer guided the students to develop topic sentence and wrote the outline to make a paragraph. It is Tekhapang traditional weapon. The following are the detail information listed by the students;

\begin{tabular}{lll}
\hline \multicolumn{1}{c}{ Local Culture } & \multicolumn{1}{c}{ Important Information } \\
\hline Tekhapang Traditional & Place & : Tulang Bawang Udik \\
Weapon & & : North Lampung \\
\cline { 2 - 3 } & Time & $:$ Since $12^{\text {th }}$ Century \\
& $:$ Tulang Bawang Kingdom \\
\cline { 2 - 3 } & Function (Today) & $:$ Marriage equipment for groom \\
\cline { 2 - 3 } & Values & Courage \\
& & - Responsibility \\
\hline
\end{tabular}

Table 2. The information of Tekhapang traditional weapon

The last phase was revising and editing. In this phase, the lecturer and the students discussed the draft had been produced by the students. Before doing the discussion, the students did peer editing with their friends. In this phase, the lecturer focuses on the use of grammar, mechanics, and vocabulary. Besides, the lecturer will check the contents of the descriptive text produced by the students. Finally, the descriptive text is published. 


\section{CONCLUSION}

Teaching and learning English is not only focusing on the linguistics competence of the learners but building good character of the learners is also important. Moreover, for millennial learners, linguistics competencies are easily obtained from their gadget. However, building good character is not easily achieved by only searching from the internet. Therefore, presenting local wisdom in teaching and learning process is one of ways to build good character of the learners. Thus, this research told the process of teaching English as Foreign Language especially writing skill. The writing skill focused on the descriptive text. It was divided in to several steps namely; planning, drafting, revising and editing. The process of internalizing the local wisdom presented in those steps. Students were presented with the local culture of Lampung such as; siger crown.

The lecturer also asked the students to find others local culture of Lampung namely; Nawo sesat traditional house, Tapis, Sigeh Pengunten dance, Melinting dance, Seruit, Sekura tradition, Tupping South Lampung, Cangget dance, Bedana dance, Tekhapang traditional weapon, Ngumbai Lawok, Ngambabekha and Ngebabali. The students found the important information as well as the values provided in the local culture. After that students were guided to write descriptive paragraph based on the local culture of Lampung. It is expected by understanding the local culture of Lampung, the values of the culture will be internalized in to habitual action of the students and create a good character. This character based local values will protect them from inappropriate target language culture being learned.

\section{REFERENCES}

Abdul, M., \& Norhasanah, N. (2019). FOUR SQUARE WRITING METHOD AS A TECHNIQUE TO TEACH DESCRIPTIVE WRITING. JEELS (Journal of English Education and Linguistics Studies), 5(2), 259-278.

Amad, S. (2017). Developing Language Students' Writing Skill by Applying Innovative Teaching Strategy Model Based on Social and Local Wisdom Contexts. Journal of Arts \&Humanities, 12 (6), 1- 6.

Arslan,A. (2008). Implementing a Holistic Teaching in Modern ELT Classes: Using Technology and Integrating Four Skills. .International Journal of Human Sciences

Alch, M. L. (2000). Get ready for a new type of worker in the workplace: The net generation. SuperVision, 61 (4), 3-7.

Dimock, M. (2019). Defining generations: Where Millennials end and Generation Z begins. Pew Research Center, 17

Frand, J. (2000). The information age-mindset: Changes in students and implications for higher education. Educause Review, 35, 14-24.

Heafner, T. L., \& McCoy, L. P. (2001). Technology and the academic and social culture of a university campus. In J. Price, D. Willis, N. Davis, \& J. Willis (Eds.), Proceedings of the society for information technology in teacher education 01 . Charlottesville: Association for the Advancement of Computing in Education

Hasyim, U. A. A., \& Suhono, S. (2017). Restoring Moslem identity by integrating Islamic values in English speaking class. ATTARBIYAH: Journal of Islamic Culture and Education, 2(1), 1-27.

Klein, L., \& Liff-Grieff, S. (2009). From generation to generation: Changing behavioural perceptions and expectations in Jewish nonprofi ts. Journal of Jewish Communal Service, $83,325-333$.

Larekang, H. S., et al. (2019). Exploring The Millennial Learners' Attributes and Needs in Educational Environment. ELS Journal on Interdisciplinary Studies in Humanities, 2 (3), 389-397

Majid, F. A., Mustafa, S. M. S., Jais, I. R. M., Shahril, W. N. E. H., Subramaniam, K., \& Halim, M. A. A. (2016). A preliminary study on selected Malaysian millennials: Their 
characteristics and its implications on teaching innovation. In 7th International Conference on University Learning and Teaching (InCULT 2014) Proceedings (pp. 685-697). Springer, Singapore

McCasland, M. (2005). Mobile marketing to millennials. Young Consumers: Insight and Ideas for Responsible Marketers, 6 (3), 8-13.

Murray, N. D. (1997). Welcome to the future: The millennial generation. NACE Journal, 57 (3), 36-42.

Promnitz-Hayashi, L. (2011). A learning success story using Facebook. Reading.

Sari, R. (2019). IMPROVING ENGLISH MEDIATED BY LOCAL WISDOM AND TECHNOLOGY IN GLOBAL ERA. KoPeN: Konferensi Pendidikan Nasional, 1(1), 212-216.

Septy, A. P. (2017). Technology Mediated literacy Education to local wisdom in English Language Teaching

Scheidet, R. A. (2003). Improving student achievement by infusing a web-based curriculum into global history. Journal of Research on Technology in Education, 36 (1), 77-94.

Schwartz, A. C., McDonald, W. M., Vahabzadeh, A. B., \& Cotes, R. O. (2018). Keeping up with changing times in education: fostering lifelong learning of millennial learners. Focus, 16(1), 74-79.

Skiba, D. J. (2008). Nursing education 2.0: Games as pedagogical platforms. Nursing Education Perspectives, 29 (3), 174-175.

Hasyim, U. A. A., \& Suhono, S. (2017). Restoring Moslem identity by integrating Islamic values in English speaking class. ATTARBIYAH: Journal of Islamic Culture and Education, 2(1), 1-27.

Puspita, N., \& Hasyim, U. A. A. (2019). Implementing Blended Learning to Promote Sustainable Teaching and Learning Process in Writing Class. English Education: Jurnal Tadris Bahasa Inggris, 12(1), 120-128. 